\title{
MORPHOFUNCTIONAL MALIGNANCY GRADING IS A VALUABLE PROGNOSTIC FACTOR FOR COLORECTAL CANCER
}

\author{
Denise Gonçalves PRIOLLI', Carlos Augusto Real MARTINEZ ${ }^{1}$, Helenice PIOVESAN², \\ Izilda Aparecida CARDINALLI ${ }^{2}$, Nelson Fontana MARGARIDO ${ }^{2}$ and Jaques WAISBERG ${ }^{3}$
}

\begin{abstract}
Context - Novel strategies are needed to identify more efficient biomarkers to accurately diagnose prognose and improve the treatment outcome of colorectal cancer. Objectives - To analyze the functional and morphological features of colorectal cancer to identify the neoplastic patterns that affect patient survival. Methods - Forty-five patients with colorectal cancer were followed for a minimum of 3 years. Blood levels of carcinoembryonic antigen (CEA) were measured by chemiluminescence and immunohistochemical analysis of tissue expression followed by computer-assisted image processing. Tumors were assigned to three morphofunctional classes. The morphofunctional classification was based on combination between histological differentiation and cell polarization. The functional characterization was based on the CEA cell polarization. The tissue polarization of CEA was classified in well-polarized, moderately polarized or nonpolarized cells. Morphofunctional staging was defined by the association between morphofunctional class (polarization and histological differentiation) and TNM by score given to each one classification. Results - There was an association between increased CEA tissue expression and loss of histological differentiation $(P=0.01)$ or loss of polarization capacity $(P=0.03)$. There was a progressive increase in tissue CEA quantities in accordance with the proposed morphofunctional grading system. Plasma levels of CEA were increased in advanced tumor stages. Blood levels of CEA were increased in advanced morphofunctional stages $(P=0.001)$. There was a relationship between survival outcome and morphofunctional staging $(P=0.005)$. Conclusion - Morphofunctional staging is a valuable prognostic factor for colorectal cancer and it correlates with plasma CEA levels. HEADINGS - Colorectal neoplasms. Carcinoembryonic antigen. Immunohistochemistry. Survival analysis. Neoplasm staging.
\end{abstract}

\section{INTRODUCTION}

Colorectal cancer (CRC) is the second most prevalent cancer worldwide and is the fourth most common cancer in men and third in women. There are an estimated 153,760 new cases each year in the United States and over 50,000 patients died from this disease in $2007^{(39)}$. In recent years, clinical, histopathologic, molecular and genetic variables have been identified that are associated with CRC patient survival ${ }^{(1,3,9,10}$, $14,15,20,24,37,39,45)$. These include early diagnosis ${ }^{(37)}$, age ${ }^{(3)}$, neoplastic site ${ }^{(46)}$, degree of histological differentiation ${ }^{(14)}$ deep wall intestinal invasion, ${ }^{(10)}$ lymph node invasion ${ }^{(1,}$ ${ }^{9)}$, mucus production ${ }^{(15)}$, carcinoembryonic antigen (CEA) serum levels ${ }^{(24)}$ angiolymphatic invasion ${ }^{(21)}$ and genomic expression profiles ${ }^{(45)}$.

There is great interest in identifying the various CRC clinical and biologic factors that are associated with neoplastic spread and CRC prognosis. There are promising results demonstrating an association between clinical and histopathological variables and CRC prognosis, but there are also results that contradict these results $^{(20,26,36,37,45)}$. Studies have attempted to identify the main factors related with CRC prognosis ${ }^{(4,29,31,3233)}$. The consensus is that the most important factors that are associated with CRC prognosis are: deep invasion into the colon wall, lymph node invasion, metastasis and degree of histological differentiation ${ }^{(22,29)}$. However, analysis based only on morphologic features acquired at a single moment in time using a microscope does not provide in-depth biological information about tumor evolution and the specific contribution of the tumor cell sub-types ${ }^{(29)}$.

Combining studies on the genetic changes, chromosomal instability, and alterations in protein expression with functional features would provide a more comprehensive basis for making CRC prognostic determinations ${ }^{(23)}$. Functional features can

\footnotetext{
Source of funding: None

All authors have no conflicts of interest.

Work performed within the Postgraduate Program in Health Science, São Francisco University Medical School, Bragança Paulista, SP. and Postgraduate Program in Surgical Gastroenterology, Federal University of São Paulo, SP, Brazil

1 Faculdade de Medicina Universidade São Francisco, Bragança Paulista, SP; ${ }^{2}$ Departamento de Cirurgia Faculdade de Medicina da Universidade de São Paulo, São Paulo, SP; ${ }^{3}$ Disciplina de Cirurgia do Aparelho Digestivo, Faculdade de Medicina do ABC, Santo André, SP, Brasil.

Correspondence: Dr. Denise Gonçalves Priolli - Rua São Vicente 614 - Jardim Paulista - 12947-390 - Atibaia, SP. - Brasil. E-mail: depriolli@terra.com.br
} 
be assayed by immunohistochemical analysis followed by computer-assisted image processing. Analyzing the functional expression of antigens associated with the development, growth and dissemination of tumor cells enables assessment of their contribution to disease progression ${ }^{(22)}$. Stepwise analysis will identify the contribution of each molecule to tumor evolution. Even though histopathological analysis is fundamental for prognosis, it is important to combine this with analysis of gene and protein expression in each neoplastic group. The principal aim of proteomic studies is the establishment of valuable prognostic tumor markers that can be used clinically. Diagnostic oncoproteomics is the application of proteomic techniques to the diagnosis of malignancies. This is essential as early detection of cancer dramatically reduces mortality.

CEA is the most commonly used tumor marker in CRC and is likely to be the most researched antigen since its initial discovery by Gold and Freedman, in $1965^{(13)}$. Studies have analyzed the prognostic power of plasma CEA levels and how it relates to morphologic features at different stages. The data generated from these studies suggests a relationship between plasma CEA levels and poor prognosis; however, there are contradicting results ${ }^{(12,14,44)}$

After resection of neoplastic lesions, CEA levels may increase and this suggests neoplastic relapse ${ }^{(5)}$, however, there are tumors that produce only small amounts of CEA. Since the CEA levels never increase in these tumors, this measurement cannot be used for detection or to assess recurrence ${ }^{(8,40)}$.

Immunohistochemical analysis of CEA expression has shown that the antigen can be expressed in different sites within tumor cells ${ }^{(16)}$. There is a relationship between intensity, the CEA cell distribution pattern and blood levels of CEA ${ }^{(6)}$. However, despite all the extensive knowledge on this protein, the relationship between plasma CEA levels and CRC stage is unknown, especially for tumors exhibiting different histological and functional features.

Currently, studies relating CEA blood levels and CRC prognosis are not guided by measurement of protein levels or antigen presentation in cancer tissue, which are important for understanding tumor protein dynamics, specifically the production and excretion capacities of the tumor cells ${ }^{(8,41)}$. These studies refer to the use of functional dynamic analysis of tumor cells. It is possible that measurement of CEA and understanding the dynamics of its production may be useful for disease prognosis.

Novel technologies are needed to identify novel and more efficient biomarkers and molecular targets for the earlier and more accurate diagnosis and treatment of CRC. Proteomics, the study of proteins and their altered regulation in disease, is a new focus of preclinical and clinical drug development. Protein arrays of tumor lysates allow assessment of the expression and activation of proteins that may be specific CRC targets or universal cancer molecular targets. Use of computer-assisted image processing allows the quantification of protein expression in tissue ${ }^{(6,34)}$.

Histological differentiation, immunoexpression and protein excretion enables classification of stages. This is necessary to individualize treatment of CRC and understand its evolution. Stratifying tumor subtypes via morphofunctional criteria assists in understanding tumor evolution within the same cancer type. Correct staging facilitates disease prognosis, because it will identify which neoplasms will behave in a similar fashion and should be treated in a similar manner. This provides insight into the biology of the disease and can be used to identify specific targets for therapeutic intervention, as well as enable monitoring of the therapeutic efficacy of the targeting the identified proteins.

The aim of this study is to analyze the functional and morphological features of CRC to determine whether neoplastic patterns are affect patient survival. The functional features involve using proteomics to assess the expression levels of CEA protein.

This study was approved by Ethics Commission of Research $(0420 / 06)$. The study comprised 45 patients (20 females) diagnosed with CRC between 2002 and 2005. The mean age was 62.47 years (range: $38-82$ ). They were classified using Dukes ${ }^{(9)}$ and $\mathrm{TNM}^{(18)}$ staging, and patients were followed for a minimum of 3 years or until death. Patients less than 18 years old were excluded. A hepatic biopsy was performed to confirm cancer. Release of CEA into the blood was measured by a chemiluminescence technique. Samples of peripheral venous blood were collected immediately prior to the operation and were sent to a laboratory for analysis.

All surgical specimens were fixed in $10 \%$ formol and embedded in paraffin blocks. Three sections of 4- $\mu \mathrm{m}$ thickness were obtained from the periphery of the tumor. Samples were stained with hematoxylin-eosin $(\mathrm{H}-\mathrm{E})$ to visualize the degree of invasion into the colon wall and extent of cell differentiation. The degree of differentiation was classified as well-differentiated, moderately differentiated or undifferentiated depending on the extent of granularization. A mucinous pattern was classified as undifferentiated, in accordance with the World Health Organization guidelines. The neoplastic involvement of the lymph nodes was evaluated using H-Estained tissue slides. All the specimens were classified using Dukes $^{(9)}$ and $\mathrm{TNM}^{(18)}$ staging.

The immunohistochemical study was performed using a previously described technique with anti-CEA monoclonal antibodies and streptavidin-biotin-peroxidase-complex ${ }^{(24)}$. The distribution patterns of staining were categorized according to the protein distribution tissue pattern and extent of protein polarization in the cells. The CEA distribution pattern in cells was classified as apicoluminal or cytoplasmic.

In regards to the polarization of CEA by the cells, normal colonocytes and neoplastic cells were compared. In normal tissue, CEA was detected as an immunostained line restricted to the apicoluminal cell surface (Figure 1A). The neoplasm was considered to be well-polarized when there was partial CEA polarization defined by CEA immunoreactivity along the cytoplasmic membrane regardless of granularization (Figure 1B). It was defined as moderately polarized when the lesions had a predominantly cytoplasmic distribution pattern (Figure 1C) and nonpolarized when the neoplasm 
had cordonal cell distribution because of the inability to distinguish the apical pole from the basal pole (Figure 1D) or when there was a large quantity of mucus in the glandular lumen, which by conventional histology would represent the mucinous pattern of CRC.

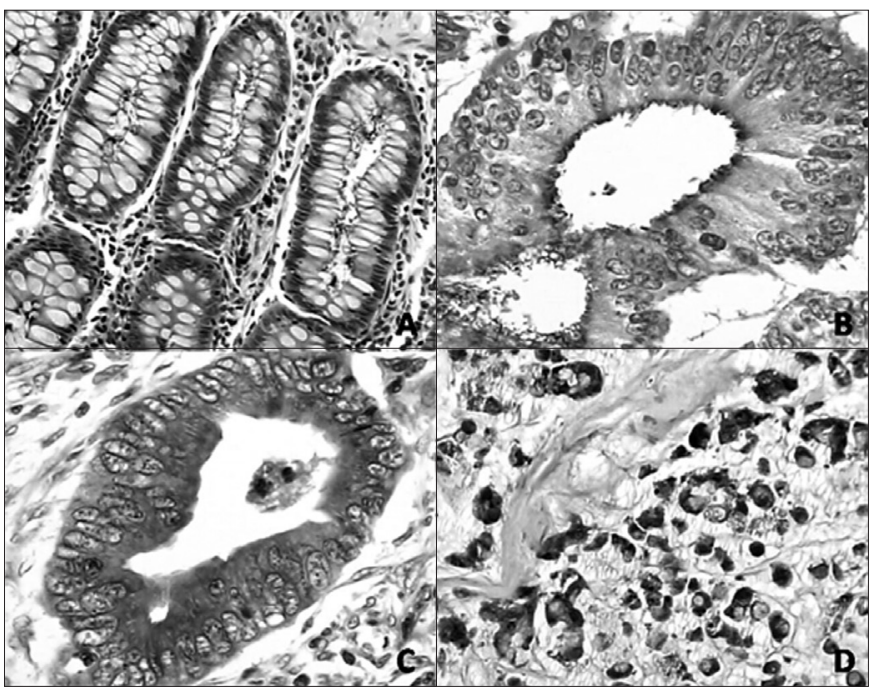

FIGURE 1. Distribution of CEA in tissue. A - Tissue expression of CEA in normal colonocytes. B - Apical distribution pattern, wellpolarized. C - Cytoplasmic distribution pattern, moderately polarized. D - Stromal distribution pattern with stromal infiltration, nonpolarized. Immunohistochemistry for CEA at 100x magnification (A) and at $400 \mathrm{x}$ magnification $(\mathrm{B}, \mathrm{C}, \mathrm{D})$

In order to measure CEA content, computer-assisted imaging processed the immunostaining information on the selected tissue as the mean obtained from three measurements taken from one same slide, following the methodology previously described ${ }^{(34)}$. The final image processing quantified the CEA expression in the tissue and generated absolute or percentage numerical values representing this expression. The average of three measurements was defined as the final value of CEA content.

The CRC specimens were categorized into three morphofunctional classes based on their functional and morphological features. The functional feature related to CEA polarization capacity and the morphological feature was based on histological grade. Well-differentiated and wellpolarized tumors were defined as morphofunctional class 1 , whereas moderately differentiated and moderately polarized carcinomas or well differentiated and moderately polarized were defined as morphofunctional class 2. Morphofunctional class 3 consisted of poorly polarized neoplastic tissue, which was independent of histological grading (Table 1).

TABLE 1. Morphofunctional classes of CRC

\begin{tabular}{lcc}
\hline Class & Histological degree & CEA polarization capacity of cells \\
\hline 1 & Well differentiated & Well polarized \\
& Moderately differentiated & Well differentiated \\
2 & Moderately differentiated & Moderately polarized \\
3 & $\begin{array}{c}\text { Moderately differentiated } \\
\text { Undifferentiated }\end{array}$ & Nonpolarized \\
\hline
\end{tabular}

Morphofunctional grading was scored based on the morphofunctional class and TNM stage (Table 2). For morphofunctional class 1 ( 1 point $)+$ TNM stage $0(0$ point), the sum is 1 . This represents morphofunctional stage I, whereas stage IV is morphofunctional class 3 (3 points) + TNM IV (4 points), resulting in a total sum of 7 points.

TABLE 2. Morphofunctional staging of CRC

\begin{tabular}{lccc}
\hline Staging & $\begin{array}{c}\text { Score } \\
\text { (total point) }\end{array}$ & $\begin{array}{c}\text { Morphofunctional Classes } \\
\text { (points) }\end{array}$ & $\begin{array}{c}\text { TNM staging } \\
\text { (points) }\end{array}$ \\
\hline I & 1 & $1(1)$ & tis (0) \\
& 2 & $1(1)$ & I (1) \\
II & 3 & $2(2)$ & \\
& 3 & $1(1)$ & II (2) \\
& 4 & $2(2)$ & \\
III & 5 & $3(3)$ & III (3) \\
& 5 & $2(2)$ & IV (4) \\
IV & 6 & $3(3)$ & \\
& 7 & $3(3)$ &
\end{tabular}

\section{Statistics}

The association between the means for the parameters of preoperative serum CEA levels, histological degree, tissue CEA content, CEA polarization capacity of cells, Dukes and TNM stage, and morphofunctional staging were compared using the Spearman test. Kaplan-Meyer survival curves were constructed and Log-Ranks were calculated to determine the prognostic outcome. The significance level was set at $5 \%$ for each analysis. All calculations were performed using SPSS 13 software.

\section{RESULTS}

The CEA levels are different when the variables of neural invasion, angiolymphatic invasion, Dukes stage ${ }^{(9)}$, TNM stage ${ }^{(18)}$ and morphofunctional stage were compared (Table 3).

There was a significant difference in the CEA content when the CEA polarization capacity of the cells, degree of histological differentiation, and morphofunctional class was compared (Table 3 ). There was increased CEA content in tumors with a poor degree of histological differentiation $(P=0.01)$ and with a progressive loss of CEA polarization in cells $(P=0.03)$. Table 4 shows a progressive increase in CEA content, which was associated with loss of the CEA polarization capacity of cells, and to a smaller degree, histological differentiation $(P=0.05)$.

The CEA content was related to the degree of histological differentiation ( $\mathrm{rs}=0.420, P=0.004)$. There was correlation between CEA levels into the blood and TNM (rs $=0.446, P=0.002$ ) and morphofunctional stage (rs $=0.439, P=0.003)$. 
TABLE 3. Comparison between variables in relation to mean CEA levels released into the blood of patients with colorectal carcinoma

\begin{tabular}{|c|c|c|c|c|c|c|c|c|}
\hline \multirow{2}{*}{ Variables } & \multirow[b]{2}{*}{ Classification } & \multicolumn{4}{|c|}{ CEA (ng/dL) } & \multicolumn{3}{|c|}{ CEA content $(\mathrm{u} / \mathrm{C})$} \\
\hline & & $\mathrm{n}$ & Mean & CI 95\% & $P$ & Mean & CI $95 \%$ & $P$ \\
\hline \multirow{2}{*}{ Neural invasion } & Absent & 34 & 5.59 & $-43.25---15.86$ & \multirow{2}{*}{0.001} & 125.55 & $-7.6-8.3$ & \multirow{2}{*}{0,70} \\
\hline & Present & 11 & 35.15 & $-55,08--4.03$ & & 125.19 & $-8.0-8.7$ & \\
\hline \multirow{2}{*}{ Angiolymphatic invasion } & Absent & 31 & 6.35 & $-34.65-6.94$ & \multirow{2}{*}{0.001} & 125.22 & $-8.2-6.6$ & \multirow{2}{*}{0.80} \\
\hline & Present & 14 & 27.15 & $-4.198-0.38$ & & 125.99 & $-8.4-8.9$ & \\
\hline \multirow{2}{*}{ Distribution pattern } & Apical & 28 & 11.63 & $-17.68-11.39$ & \multirow{2}{*}{0.61} & 127.02 & $-2.86-1.12$ & \multirow{2}{*}{0.65} \\
\hline & Cytoplasmic & 17 & 14.77 & $-18.25-11.97$ & & 122.89 & $-2.93-1.19$ & \\
\hline \multirow{3}{*}{ CEA polarization capacity of cells } & Well polarized & 23 & 8.63 & $-1.04-18.31$ & \multirow{3}{*}{0.37} & 125.35 & $121.31-130.39$ & \multirow{3}{*}{0,0} \\
\hline & Moderately polarized & 18 & 15.56 & $3.07-28.04$ & & 122.10 & $116.70-27.51$ & \\
\hline & Unpolarized & 4 & 24.55 & $-3.5-52.62$ & & 138.34 & $121.2-155.46$ & \\
\hline \multirow{3}{*}{ Degree of histological differentiation } & Well differentiated & 12 & 11.58 & $0.76-22.40$ & \multirow{3}{*}{0.58} & 119.86 & $114.63-25.09$ & \multirow{3}{*}{0,0} \\
\hline & Moderately differentiated & 29 & 11.71 & $1.79-21.62$ & & 126.01 & $121.74-130.26$ & \\
\hline & Undifferentiated & 4 & 24.55 & $-3.5-52.62$ & & 138.34 & $121.21-155.46$ & \\
\hline \multirow{3}{*}{ Dukes staging } & A & 4 & 4.25 & $-2.2-10.7$ & \multirow{3}{*}{0.02} & 128.40 & $105.48-151.33$ & \multirow{3}{*}{0.65} \\
\hline & B & 27 & 7.09 & $2.6-11.5$ & & 126.14 & $121.29-130.99$ & \\
\hline & $\mathrm{C}$ & 14 & 26.32 & $5.6-47.03$ & & 123.31 & $118.23-128.39$ & \\
\hline \multirow{4}{*}{ TNM staging } & I & 0 & - & - & \multirow{4}{*}{0.001} & - & - & \multirow{4}{*}{0.66} \\
\hline & II & 31 & 6.72 & $2.86-10.58$ & & 126.43 & $121.91-130.95$ & \\
\hline & III & 10 & 8.18 & $2.63-13.72$ & & 123.98 & $117.56-130.40$ & \\
\hline & IV & 4 & 71.68 & $8.9-134.44$ & & 121.63 & $106.65-136,60$ & \\
\hline \multirow{3}{*}{ Morphofunctional class } & 1 & 23 & 8.63 & $-1.04-18.31$ & \multirow{3}{*}{0.37} & 125.85 & $121.31-130.39$ & \multirow{3}{*}{$0,0^{3}$} \\
\hline & 2 & 18 & 15.56 & $3.07-28.04$ & & 122.10 & $116.70-127.51$ & \\
\hline & 3 & 4 & 24.55 & $-3.52-52.62$ & & 138.34 & $121.21-155.46$ & \\
\hline \multirow{4}{*}{ Morphofunctional staging } & I & - & & & \multirow{4}{*}{0,001} & - & - & \multirow{4}{*}{0.63} \\
\hline & II & 19 & 4.51 & $0.77-8.2$ & & 126.13 & $120.85-131.41$ & \\
\hline & III & 23 & 12.93 & $2.63-23.24$ & & 125.84 & $120.40-131.27$ & \\
\hline & IV & 4 & 51.65 & $6.32-109.00$ & & 120.22 & $106.76-133.67$ & \\
\hline
\end{tabular}

$\mathrm{CI}=$ confidence interval;

$P=$ significance

TABLE 4. CEA content associated with histological differentiation and the CEA polarization capacity of the cell

\begin{tabular}{lccc}
\hline Variables degree of differentiation & well & $\begin{array}{c}\text { CEA polarization capacity of cells } \\
\text { moderately }\end{array}$ & unpolarized \\
\hline Well differentiated & 121.19 & 118.53 & $P$ \\
Moderately differentiated & 127.49 & 123.89 & 138.34 \\
Undifferentiated & & & 0,05 \\
\hline
\end{tabular}

$P=$ significan

\section{DISCUSSION}

In spite of technological advancements, worldwide cancer deaths are projected to continue rising, with 9 million estimated deaths in 2015 and 11.4 million in $2030^{(38)}$. The variability in clinical and biological behavior has aroused interest in identifying factors associated with disease progression and prognosis. Recently, clinical, histopathologic, molecular and genetic variables have been associated with survival outcome in CRC patients ${ }^{(1,3,9,10,14,15,20,22,24,29,35,45,46)}$. Factors such as deep tumor infiltration into the colon wall, lymph node infiltration, metastasis and histological degree have been investigated as prognostic markers ${ }^{(23,35)}$. Assessing prognosis only using morphologic criteria is limited as it only represents a specific moment in time of tumor evolution. It does not provide information about tumor dynamics.

Comprehension of genetics changes involved in CRC, chromosomal instability and proteomic expression makes the possibility of using functional features valuable to improve the efficiency of CRC prognosis ${ }^{(31)}$. Oncoproteomics is the study of proteins and their interactions in a cancer cell by applying proteomic methodologies. Analysis of cell dynamics is possible because of advancements in molecular biology and analysis of antigens associated with development. The growing and spreading of a tumor occurs as a consequence of the specific expression of proteins. This possibility allows the analyses of functionally dynamic neoplasia and whether it correlates with cancer prognosis ${ }^{(23)}$.

The stepwise identification of the functional relationship of each molecule will elucidate unknown aspects of CRC evolution. These phenomena are very important to comprehend the unexplained pathological events that contribute to CRC. There is intense interest in applying proteomics to improve our understanding of cancer pathogenesis, develop new tumor biomarkers for diagnosis and early detection by analyzing the proteomic content of samples. Although histopathology remains a fundamental element for prognostic analysis, additional methods that study neoplastic gene and protein expression are making their way into clinical practice. The study of oncoproteomics provides further understanding about each neoplastic group, 
and the main goal is to establish the prognostic value of a tumor marker that has utility in clinical practice.

CEA is a tumor marker that has been extensively studied in $\mathrm{CRC}^{(44)}$. It is not used as a diagnostic tool because of its low specificity, but it is important to measure levels of this protein in patients that have undergone surgical resection, especially CRC patients ${ }^{(20)}$. When the levels of a tumor marker increase in the circulation after a complete tumor resection, it can indicate relapse, but some tumors produce small amounts of CEA and an increased level does not necessarily mean disease recurrence ${ }^{(8,44)}$. There is controversy regarding the relationship between CEA blood levels and CEA tissue expression as assessed by immunohistochemistry using antiCEA antibodies in CRC specimens ${ }^{(28,41)}$. Studies reporting on the prognostic power of blood protein quantification correlate CEA expression with valid morphologic variables, represented by different forms of staging, and show an association between increased CEA blood levels and an unfavorable prognosis.

In the present study, CEA blood levels varied between 0.1 $\mathrm{ng} / \mathrm{dL}$ and $106 \mathrm{ng} / \mathrm{dL}$ in a patient with early disease and in a patient with liver metastasis, respectively. This association is dependent on the neoplastic stage since the release of CEA into the blood is determined by the tumor size and presence of metastatic tumors that produce the CEA. In addition, an advanced-staged neoplasia exhibits deep infiltration, which allows easy access of CEA to the circulation and increases tumor marker levels in the blood ${ }^{(13,27,29)}$. The results obtained in the present study support a correlation between the Dukes ${ }^{(9)}, \mathrm{TNM}^{(18)}$ and morphofunctional classifications and increased CEA levels in advanced stages of neoplasia. These results demonstrate a rise in CEA levels in the blood, which is associated with disease progression, although, current studies relating CEA and prognostic classification are controversial ${ }^{(5,12,44)}$. An increase in CEA levels after complete resection can suggest cancer recurrence ${ }^{(8)}$, but there is a subset of CRC tumors that produce a small quantity of CEA and blood levels remain normal. In these circumstances, the measurement of CEA levels in the blood does not relate to advanced disease detection or recurrence ${ }^{(16,41)}$. In despite of the extensive knowledge on this protein, the relationship between CEA levels and CRC staging remains undefined when tumors with different morphologic and functional features are considered.

CEA immunoexpression was identified in all normal and neoplastic colorectal tissues. In other studies, the immunostaining rate for neoplastic cells ranges from $20 \%$ to $100 \% 0^{(6,17,19,30,40,41,43)}$. The differences in the extent of immunostaining between our and other studies may be due to different staining methodologies.

In the neoplastic cell population, the staining was apical in $62.2 \%$ and was cytoplasmic in the remaining $37.8 \%$. Stromal immunostaining was observed in $100 \%$ of the specimens when there was rupture of the basal membrane, which characterized an invasive phenotype. Therefore, we can conclude that stromal distribution is a manifestation of the invasive properties of a tumor, which is a view accepted by other authors ${ }^{(2,6,7,30,41)}$. Assessing CEA expression by means of immunohistochemistry has demonstrated that the antigen can be expressed in different sites in CRC cells and there is a relationship between intensity, tissue staining pattern and CEA blood levels ${ }^{(6,16)}$. This current study shows a correlation between CEA and CRC prognosis and indicate that it is important to not only quantify the tumor marker levels in the blood but also to consider the expression of the antigen in tumor tissue. Considering the latter reveals important protein dynamics, which include production and excretion of the specific antigen ${ }^{(41)}$.

The cell surfaces in contact with the lumen of the colon have microvilosities that mediate absorption and excretion. Normal mucosal cells produce antigen that moves into the cytoplasm and associates with the cell membrane and is subsequently eliminated from the cell into the lumen ${ }^{(39)}$. Proteins produced in the mucosal cells of the specialized colonic epithelium maintain their polarization, as is the case for CEA. In normal colonic epithelium there is an increase in cytoplasmic CEA with a low degree of differentiation, suggesting that an incapacity for cell polarization is related to reduced cell specialization $^{(13,39)}$. This study showed that differential antigen content in tumors correlated with a progressive loss of cell polarization capacity. During specialization, mucosal cell processes move from the deep crypts, which are part of the proliferative epithelium zone, to apical regions and become further differentiated ${ }^{(11)}$. The relationship between cell specialization, intensity and tissue expression of CEA

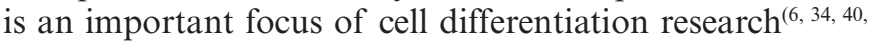
${ }^{47)}$. However, other authors contradict this role for $\mathrm{CEA}^{(23,39)}$. in the present study, we did not find an association between CEA blood levels and the degree of differentiation, but there is an increase in tissue protein content, which is related to the degree of differentiation and cell polarization capacity. Hamada at al. ${ }^{(16)}$ showed that most patients with well-differentiated tumors had an apical distribution pattern CEA and a low level in the blood. Patients with well-differentiated tumors with an apical staining pattern show low levels of CEA in the blood, whereas patients with moderately differentiated or undifferentiated tumors with a cytoplasmic staining pattern have high levels of CEA in the blood ${ }^{(44)}$. Patients with welldifferentiated carcinomas, moderate to intense expression and an apical distribution pattern may present with low blood levels of CEA, because although the antigen is present in the tissue, the majority of it is eliminated by the intestinal lumen ${ }^{(47)}$. Our findings support this conclusion. There is an increased protein content in tumors with a low degree of differentiation and with a progressive loss of cell polarization capacity. There is a progressive increase in tissue levels of CEA with a low degree of differentiation associated with a loss of cell polarization capacity in accordance with the proposed morphofunctional grading.

An in vitro study showed that a CRC matrix that originated in a LISP-I cell line consisted of two morphologically distinct subpopulations, LISP-A10 and LISP-E11. Morphological differences were shown to correlate with diverse functional properties that probably contributed to the metastasis of the LISP-1 cell line. LISP-A10 cells expressed higher amounts 
of CEA on their cell surface as compared to LISP-E11, which is similar to a CRC undifferentiated pattern ${ }^{(41)}$. These aspects demonstrate the importance not only of the degree of differentiation but also the capacity of the neoplastic cells to produce the tumor antigen. Thus, classification considering morphological and functional characteristics can direct the prognostic meaning of high blood levels of CEA.

In the present study, the CEA blood levels were higher in the morphofunctionally-defined advanced stage. It reinforces the concept that the diverse characteristics of colon cells, as defined morphofunctionally, critically contribute to the levels of CEA in the circulation.

Despite the controversy concerning the validity of measuring the pre-operative levels of CEA, our studies emphasize their value and demonstrate an association between higher levels of CEA and poorer prognosis ${ }^{(12,42)}$. Some research contradicts these findings and show that $14 \%$ to $56 \%$ of CRC cases can present with normal blood levels of CEA ${ }^{(44,47)}$. Thus, measuring CEA levels before surgical treatment remains controversial. The CRC classification systems are based on information related to the extent of disease, and are important for deciding on a treatment strategy. There have been many attempts to identify an efficient classification system for CRC. The Dukes system proposed the most simple classification that add up infiltration deep into tissue and metastasis ${ }^{(9)}$. In 1945, Dukes classification was extended to colon cancer and almost 10 years later, Astler and Coller ${ }^{(1)}$ proposed a new modification. In 1966, studies focused on developing new cancer classifications resulted in the publication of the first TNM classification system (Tumor, Node, Metastasis) ${ }^{(18)}$. TNM is the most commonly used classification. It has $65 \%$ accuracy but fails to estimate prognosis in some patients ${ }^{(27)}$, especially stage II and III patients. Therefore, this is not useful for generating a consensus on a chemotherapeutic treatment strategy ${ }^{(25,27)}$. Classification by functional, clinical and morphological features provides stratification of groups that results in a more valid prognosis with a greater certainty ratio. The Colorectal Working Group guidelines recommend measuring pre-operative CEA blood levels as a prognostic factor when associated with TNM stage. In the present study, when functional aspects were considered with TNM staging, there was a relationship between survival outcome and CEA blood levels. Additionally, there was significance between stage II and III of morphofunctional classification. This study showed (Figure 2) that the results from the survival curves generated from morphofunctional staging rather than TNM staging were more statistically significant $(P=0,005)$. In this study, the importance of including functional variables in staging was evident when considering CEA blood levels and morphofunctional staging (Tables 1 and 3), especially for stages II and III. The difference is more evident in morphofunctional staging than TNM staging. Staging based only on morphological features does not provide information about the evolution of intermediate stages of disease, so no consensus can be reached regarding appropriate therapy for these cases. The morphofunctional staging not only considers the morphological characteristic but also the cellular protein dynamics, and it supports using CEA measurement as a prognostic factor for CRC. It is better than TNM classification as it considers invasiveness and aggressiveness, which both arise from tumor genotype. Indirect analyses of gene expression by the detection of the corresponding encoded proteins, such as CEA, provide functional analysis related to tumor development, growth and dissemination. In this regard, it is important to analyze the dynamic cellular functions as these are factors that may be associated with disease prognosis, as they arise from mutations acquired by colon cells ${ }^{(32)}$.
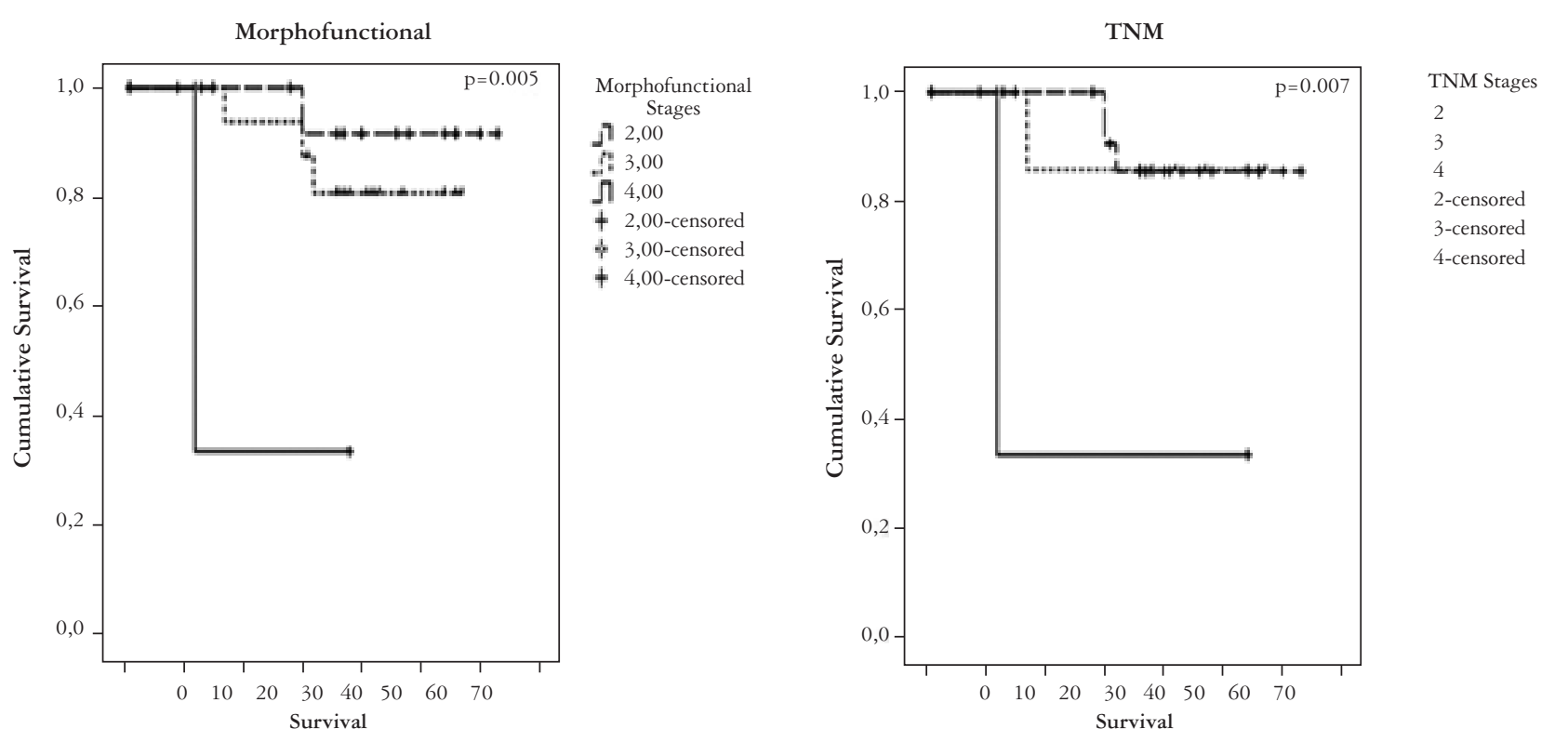

FIGURE 2. TNM and morphofunctional survival curves 
The present study suggests that there are two mechanisms responsible for the increase in CEA levels in the blood of CRC patients. The first mechanism is due to altered production and excretion of proteins from tumor subpopulations and a loss of cell polarization capacity. The second mechanism is through total mass production of antigen and deep infiltration into the colon wall (TNM). The potential to analyze both simultaneously enables the development of a new classification system, which is useful in predicting CRC that is specifically related to CEA levels in the blood.

Understanding the molecular basis of the biochemical pathways involved in carcinogenesis facilitates the integration of diagnosis, anticancer drug discovery, and therapeutic strategies for cancer. One of the major contributions of proteomics to the medical and pharmaceutical fields is the identification of potential drug targets. Many cancers are characterized by alterations in specific signaling pathways and identification of the aberrant pathway in an individual patient enables targeted therapy. Prognostication and the variability of tumor responses to radio/chemo-therapeutic agents is a major interest in cancer research. The advances in proteomic research will lead to a plethora of new molecular markers, which are likely to correlate with the progression of the disease and survival outcome.

Based on our results, we propose that staging considers morphologic and functional features in combination with histological degree of neoplasia, immunoexpression and protein tissue excretion. This will enable greater comprehension of disease evolution. This classification that utilizes morphofunctional aspects to distinguish between different profiles from similar tumors allows precise prognosis of disease progression.

\section{CONCLUSION}

From the results of this study, despite small data, it can be concluded, that morphofunctional staging should be considered when evaluating the prognosis of CRC patients, because it considers both functional cell dynamics and CEA levels in the blood. Further research with a larger cohort of patients is necessary to confirm the significance of these findings.

Priolli DG, Martinez CAR, Piovesan H, Cardinalli IA, Margarido NF, Waisberg J. Graduação morfofuncional de malignidade como valioso fator prognóstico para o câncer colorretal. Arq Gastroenterol. 2010;47(3):225-32.

RESUMO - Contexto - Novas estratégias são necessárias à identificação de marcadores que promovam precisão no diagnóstico, no prognóstico e melhorem o tratamento de pacientes com câncer colorretal. Objetivo - Analisar características funcionais e morfológicas do câncer colorretal para identificar padrões de neoplasia que modificam a sobrevida. Métodos - Quarenta e cinco pacientes com adenocarcinoma colorretal foram seguidos por no mínimo 3 anos. Níveis séricos de antígeno carcinoembrionário (CEA) foram mensurados por quimioluminescência e a análise imunoistoquímica da expressão tecidual do antígeno por meio de processamento de imagem assistida por computador. Tumores foram divididos em três classes morfofuncionais. A classificação morfofuncional foi baseada na combinação entre grau histológico e polarização do CEA celular. A polarização do CEA foi classificada em bem polarizada, moderadamente polarizada e não-polarizada. O estádio morfofuncional foi definido pela associação entre as classes morfofuncionais (polarização e grau histopatológico) e pontuação dada a cada uma das classificações. Resultados - Houve associação entre aumento de expressão de CEA tecidual e perda do grau de diferenciação $(P=0.01)$ ou perda da capacidade de polarização $(P=0.03)$. Houve aumento progressivo dos níveis de proteínas teciduais em acordo com o sistema de classificação morfofuncional proposto. Níveis plasmáticos de CEA estavam aumentados com a progressão dos estádios tumorais $(P=0.001)$. Houve relação entre sobrevida e estádio morfofuncional $(P=0.005)$.

Conclusão - Estádio morfofuncional é um valioso fator prognóstico para o câncer colorretal e se correlaciona com níveis séricos de CEA.

DESCRITORES - Neoplasias colorretais. Antígeno carcinoembrionário. Imunoistoquímica. Análise de sobrevida. Estadiamento de neoplasias.

\section{REFERENCES}

1. Astler VB, Coller FA. The prognostic significance of direct extension of carcinoma of the colon and rectum. Ann Surg. 1954;139:846-51.

2. Battistelli S, Marcheggiani F, Stella F, Pecorella I, Troccoli R. Histochemical demonstration of CEA in pathology of the colorectum. Boll Soc Ital Biol Sper. 1990;66:985-92.

3. Cain AS, Longino LA. Carcinoma of the colon in children. J Pediatr Surg. 1970;5:527-32.

4 Castells A, Bessa X, Daniels M, Ascaso C, Lacy AM, García-Valdecasas JC, Gargallo L, Novell F, Astudillo E, Filella X, Piqué JM. Value of postoperative surveillance after radical surgery for colorectal cancer. Dis Colon Rectum. 1998;41:714-24.

5 Chapman MA, Buckley D, Henson DB, Armitage NC. Preoperative carcinoembryonic antigen is related to tumor stage and long-term survival in colorectal cancer. $\mathrm{Br}$ J Cancer. 1998;78:1346-9

6 Chiquillo Barber MT, Bort Marti I, Navarro Fos S, Perez Bacete M, Esclápez Valero J, Gómez-Ferrer Bayo F. A correlation between serum levels of preoperative CEA and CEA immunohistochemical staining in colorectal carcinoma. Rev Esp Enferm Dig. 1993;83:249-54.
7. Chiquillo Barber MT, Navarro Fos S, Perez Bacete M, Esclápez Valero JP, Gómez-Ferrer Bayo F, Bort Marti J. The determination of tissue CEA in colorectal adenocarcinomas: an immunohistochemical study. Rev Esp Enferm Dig. 1993;83:241-7.

8. Costa CA, Macedo JLS, Reis PEC, Povoa C, Mendes D, Magalhães E, Paes E, Yamagushi N. O valor do CEA no estadiamento do adenocarcinoma colorretal. Rev Bras Cir. 1996;86:171-3.

9. Dukes CE. The classification of cancer of the rectum. J Pathol Bacteriol. 1932;35:323-32.

10. Dukes CE, Bussey HJ. The spread of rectal cancer and its effect on prognosis. $\mathrm{Br}$ J Cancer. 1958;12:309-20.

11. Fantini J, Rognoni JB, Culouscou JM, Pommier G, Marvaldi J, Tirard A. Induction of polarized apical expression and vectorial release of carcinoembryonic antigen (CEA) during the process of differentiation of HT29-D4 cells. J Cell Physiol. 1989;141:126-34.

12. Forones NM, Tanaka M. CEA and Ca 19-9 as prognostic indexes in colorectal cancer. Hepatogastroenteroly. 1999;46:905-8.

13. Gold P, Freedman SO. Demonstration of tumor-specific antigens in human colonic carcinoma by immunological tolerance and absorption techniques. J Exp Med. 1965;121:439-62. 
14. Grinnel RS. The grading and prognosis of carcinoma of the colon and rectum. Ann Surg. 1939;109:500-33.

15. Halvorsen TB, Seim E. Influence of mucinous components on survival in colorectal adenocarcinomas: a multivariate analysis. J Clin Pathol. 1988;41:1068-72.

16. Hamada Y, Yamamura M, Hioki K, Yamamoto M, Nagura H, Watanabe K. Immunohistochemical study of carcinoembryonic antigen in patients with colorectal cancer. Correlation with plasma carcinoembryonic antigen levels. Cancer 1985;55:136-41

17. Huitric E, Laumoniec R, Burtin P, Von Kleist S, Chavonel G. An optical and ultrastructural study of the localization of carcinoembryonic antigen (CEA) in normal and cancerous human retocolonic mucosa. Lab Invest. 1976;34:97-107.

18. International Union Against Cancer. Committee on TNM Classification. Malignant tumors of oesophagus, stomach, colon and rectum. Geneve: UICC; 1966.

19. Kemeny N, Braun DW Jr. Prognostic factors in advanced colorectal carcinoma. Importance of lactic dehydrogenase level, performance status, and white blood cell count. Am J Med. 1983;74:786-96.

20. Khankhanian N, Mavligit GM, Russell WO, Schimek M. Prognostic significance of vascular invasion in colorectal cancer of Dukes' B class. Cancer. 1977;39:1195-200.

21. Knudsen JB, Nilsson T, Sprechler M, Johansen A, Christensen N. Venous and nerve invasion as prognostic factors in postoperative survival of patients with resectable cancer of the rectum. Dis Colon Rectum. 1983;26:613-7.

22. Kune GA, Kune S, Field B, White R, Brough W, Schellemberger R, Watson LF. Survival in patients with large-bowel cancer. A population-based investigation from Melbourne Colorectal Cancer Study. Dis Colon Rectum. 1990;33:938-46.

23. Markova E, Kamenova M. Study of the tissue localization of carcinoembryonic antigen in tumors of colonic mucosa. Eksp Med Morfol. 1989;28:12-6.

24. Martinez CAR, Priolli DG, Cardinalli IA, Piovesam H, Pereira JA, Waisberg J, Margarido NF. Correlação entre o padrão de distribuição tecidual e os valores séricos do antígeno carcinoembrionário em doentes com câncer. Rev Bras Coloproctol. 2006;26:41-53.

25. Michelassi F, Vanucci L, Ayala JJ, Chappel R, Goldberg R, Block GE. Local recurrence after curative resection of colorectal adenocarcinoma. Surgery. 1990;108:787-93

26. Moertel CG, Schutt AJ, Go VL. Carcinoembryonic antigen test for recurrent colorectal carcinoma. Inadequacy for early detection. JAMA. 1978;239:1065-6.

27. Nathanson SD, Shultz L, Tilley B, Kambouris A. Carcinomas of the colon and rectum: a comparative of staging classifications. Am Surg. 1986;52:428-33.

28. Pagé M, Dalifard I, Bertrand G, Bocquillon PG, Daver A. Immunostaining of colorectal cancer with monoclonal anti-CEA antibodies compared to serum and tumor CEA content. Anticancer Res. 1986;6:893-6.

29. Phillips RK, Hittinger R, Blesowsky L, Fry JS, Fielding LP. Large bowel cancer: surgical pathology and its relationship to survival. Br J Surg. 1984;71:604-10.

30. Pihl E, McNaughton J, Ward HA, Nairn RC. Immunohistological patterns of carcinoembryonic antigen in colorectal carcinoma. Correlation with staging and blood levels. Pathology. 1980;12:7-13.

31. Pinho MSL. Estadiamento molecular do câncer colorretal: o futuro se aproxima. Rev Bras Coloproctol. 2005;25:279-84.

32. Ponz de Leon M, Sant M, Micheli A, Sacchetti C, Di Gregorio C, Fante R, Zanghieri G, Melotti G, Gatta G. Clinical and pathologic prognostic indicators in colorectal cancer. A population-based study. Cancer. 1992;69:626-35.
33. Priolli DG, Margarido NF, Martinez CAR, Rotta CM, Stephani SM. Edema quantification by computadorized morphometry as an evaluation parameter for the resistence of colon anastomoses. Acta Cir Bras. 2003;18:398-406.

34. Priolli DG, Martinez CAR, Margarido NF, Rotta CM, Nakano SMS, Garcia MBO. Avaliação da pressão de explosão e da dosagem tecidual de colágeno nas anastomoses colorretais realizadas com e sem preparo de cólon - Estudo experimental em ratos. Rev Bras Coloproctol. 2005;25;12-23.

35. Rich T, Gunderson LL, Lew R, Galdibini JJ, Cohen AM, Donaldson G Patterns of recurrence of rectal cancer after potentially curative surgery. Cancer. 1983;52:1317-29.

36. Sanfelippo PM, Beahrs OH. Factors in the prognosis of adenocarcinoma of the colon and rectum. AMA Arch Surg. 1972;104:401-6.

37. Schoentag R, Williams V, Kuhns W. The distribuition of blood group substance $\mathrm{H}$ and CEA in colorectal carcinoma. Cancer. 1984;53:503-9.

38. Surveillance Epidemiology and End Results - SEER. National Cancer Institute Colon and rectum. [cited 2008 mar 21]. Available from: http://seer.cancer.gov/ statfacts/html/colorect/html.

39. Shirota K, Minassian H, Jothy S. Protein G-gold immunoelectron microscopy of the colon carcinoma: the effect of tumor differentiation of carcinoembryonic antigen immunostaining. Exp Mol Pathol. 1988;49:305-15.

40. Sirigu F, Dessi A, Natale L. Tissue carcinoembryonic antigen in norma conditions and neoplastic pathology of the colorectum. Recenti Prog Med 1991;82:378-80.

41. Solimene AC, Carneiro CR, Melati I, Lopes JD. Functional differences between two morphologically distinct cell subpopulations within a human colorectal carcinoma cell line. Braz J Med Biol Res. 2001;34:653-61.

42. Sunouchi K, Machinami R, Mori M, Namiki K, Hattori S, Murata Y, Tsuchiya T, Mizuno H, Tadokoro M. Clinical impact of carcinoembrionic antigen messenger ribonucleic acid expression in tumor-draining vein blood on postoperative liver metastasis in patients with colorectal carcinoma: a prospective cohort study. Dis Colon Rectum. 2003;46:467-73.

43. Tokunaga N, Kijima H, Noto T, Osamura Y, Sadahiro S, Tajima T, Mitomi T. Immunohistochemical localization of carcinoembryonic antigen as a predictor of lymph node status in submucosa-invasive colorectal carcinoma. Dis Colon Rectum. 1995;38:842-7.

44 Wang JY, Tang R, Chiang JM. Value of carcinoembryonic antigen in the management of colorectal cancer. Dis Colon Rectum. 1994;37:272-7.

45 Wang Y, Jatkoe T, Zhang Y, Mutch MG, Talantov D, Jiang J, McLeod HL, Atkins D. Gene expression profiles and molecular markers to predict recurrence of Dukes' B colon cancer. J Clin Oncol. 2004;22:1564-71.

46 Wolmark N, Wieand HS, Rockette HE, Fischer B, Glass A, Lawrence W, Lerner $\mathrm{H}$, Cruz AB, Volk H, Shibata H. The prognostic significance of tumor location and bowel obstruction in Dukes B and C colorectal cancer. Findings from the NSABP clinical trials. Ann Surg. 1983;198:743-52.

47 Zeng Z, Cohen AM, Urmacher C. Usefulness of carcinoembryonic antigen monitoring despite normal preoperative values in node-positive colon cancer patients. Dis Colon Rectum. 1993;36:1063-8. 